\title{
REGULARITIES OF RESTORATION OF NFS \\ INDICATORS OF DISABLED ATHLETES AFTER COMPLETION OF MUSCLE LOADING DEPENDING ON THE DEGREE OF LOWER LIMBS
}

\section{REGULARIDADES DE LA RESTAURACIÓN DE LOS INDICADORES NFS DE ATLETAS CON DISCAPACIDAD DESPUÉS DE LA TERMINACIÓN DE LA CARGA MUSCULAR SEGÚN EL GRADO DE LOS MIEMBROS INFERIORES}

\author{
L.I. Vakhitov', T.L. Zefirov', Yu.V. Valeeva' ${ }^{1}$, I.Kh. Vakhitov ${ }^{1}$ \\ ${ }^{1}$ Kazan Federal University, 420008, Kazan, ul. Kremlyovskaya, 18 \\ Bulat.vakhitov.1989@mail.ru
}

Enviado: 27 de junio de 2019

Aceptado para publicar: 30 de julio de 2019

Publicado: 8 de agosto de 2019

\begin{abstract}
In this article, the reaction of heart rate and stroke volume of athletes with disabilities to the performance of a standardized muscular load and the characteristics of their recovery after the completion of the load was studied. Athletes are divided into two groups. The first groups are wheelchair basketball players with amputated lower limbs. The second group is wheelchair basketball players with lower limb atrophy. A comparative analysis of heart rate and stroke volume was performed at rest when performing a muscular load and after it was completed. It was revealed that among basketball players with amputated lower limbs, heart rate indices are higher, while the values of ASW are significantly lower than among basketball players with atrophy of lower limbs. It has been established that basketball players with amputated lower limbs react to muscle load with large changes in AEC than athletes with atrophied lower limbs. It was revealed that basketball amputated lower limbs recovery of heart rate and CRM approximately to the level of the initial values after the completion of muscle load occurs much faster than basketball players with atrophy of the lower extremities.
\end{abstract}

Keywords: wheelchair basketball players, muscle loads, heart rate, stroke volume, recovery period, heart pump function.

En este artículo, se estudió la reacción de la frecuencia cardíaca y el volumen sistólico de los atletas con discapacidades al desempeño de una carga muscular estandarizada y las características de su recuperación después de completar la carga. Los atletas se dividen en dos grupos. Los primeros grupos son jugadores de baloncesto en silla de ruedas con miembros inferiores amputados. El segundo grupo son los jugadores de baloncesto en silla de ruedas con atrofia de las extremidades inferiores. Se realizó un análisis comparativo de la frecuencia cardíaca y el volumen sistólico en reposo cuando se realizó una carga muscular y después de que se completó. Se reveló que entre los jugadores de baloncesto con miembros inferiores amputados, los índices de frecuencia cardíaca son más altos, mientras que los valores de ASW son significativamente más bajos que entre los jugadores de baloncesto con atrofia de miembros inferiores. Se ha establecido que los jugadores de baloncesto con miembros inferiores amputados reaccionan a la carga muscular con grandes cambios en la AEC que los atletas con miembros inferiores atrofiados. Se reveló que el baloncesto amputó la recuperación de la frecuencia cardíaca y la CRM de las extremidades inferiores aproximadamente al nivel de los valores iniciales después de que se completa la carga muscular mucho más rápido que los jugadores de baloncesto con atrofia de las extremidades inferiores.

Palabras clave: jugadores de baloncesto en silla de ruedas, cargas musculares, frecuencia cardíaca, volumen sistólico, período de recuperación, función de bombeo cardíaco. 


\section{Introduction}

The works of domestic and foreign experts indicate that the most effective method for the rehabilitation of disabled people is the use of physical culture and sports [1,5-9,17]. However, the features of the impact of systematic muscle training on the body of persons with disabilities are not fully understood. Of the few studies that characterize Paralympians with lesions of the musculoskeletal system, only a few are devoted to wheelchair basketball.

Constantly increasing norms to the level of physical fitness of athletes with disabilities, in our opinion, require consideration of both the individual characteristics of the athlete and the characteristics of injuries. Under the influence of intense sports loads in athletes with disabilities, mechanisms of adaptation and compensation for serious congenital or acquired pathologies are forming. At the same time, the mechanisms of urgent and long-term adaptation of athletes with disabilities to systematic muscle training are not well understood.

Persons with various lesions of the musculoskeletal system have different morphofunctional and psychophysiological indicators that are not sufficiently studied. Considerable interest among researchers is the study of patterns of changes in the pumping function of the heart during systematic muscle training [2-4,10,11,16].

For a more complete picture of the functional capabilities of the heart, it is advisable to research the activity of the heart directly while performing muscular loads. At the same time, changes in the indices of the pumping function of the heart in the recovery process, especially immediately after the cessation of muscular activity, indicate the most important regulatory alterations in the body $[2,3,4]$. It should be noted that the works devoted to the study of wheelchair basketball players are few. In literary sources, extremely rarely found work devoted to the study of the functional possibilities of the heart of persons with disabilities during systematic muscle training. In this regard, we investigated the response of indicators of the stroke volume of blood of athletes with disabilities depending on the degree of damage to the lower limbs when performing muscular load and especially its recovery after the completion of the load.

The purpose of these studies was to study the characteristics of changes in the pumping function of the heart in athletes with disabilities, depending on the degree of damage to the lower extremities.

Objectives of the study:

1. To study the reaction of the heart rate and stroke volume of blood of disabled athletes with amputation and atrophy of the lower extremities when performing a muscular load.

2. To analyze the features of the recovery of the heart rate and CRM of disabled athletes with amputation and atrophy of the lower limbs after the completion of the muscular load.

\section{Research Methodology}

Studies were conducted among disabled athletes of the Wings of Barca basketball team. The total number of athletes surveyed was 20 people. Athletes were conditionally divided into two groups. The first group included athletes with amputation of the lower extremities ( 9 people). The second group consisted of 11 people with atrophy of the lower extremities. The study of indicators of the pumping function of the heart (NSF) was carried out in two stages. In the first stage, the NFS indicators of disabled athletes alone were examined. In the second stage, the disabled athletes performed the muscular load in the form of shuttle acceleration for 3 minutes along the perimeter of the basketball court, then the features of the recovery of the heart's pumping function were analyzed.

To assess the reliability of differences, the standard values of the Student's t-test were used.

\section{Rheogram registration technique.}

Among rheographic methods for determining the stroke volume of blood, the most widely used method of tetrapolar thoracic rheography according to Kubitschek [12] in various modifications. The non-invasive nature of the method, its prostate and its availability for practical use make it one of the most promising methods for determining heart rate.

Electrodes are superimposed according to the diagram; 2 current electrodes: the first - on the head in the forehead, the second - on the lower leg above the ankle joint, 2 measuring electrodes: the first - in the neck at the level of the 7 th cervical vertebra, the second - in the chest at the level of the xiphoid process.

Chest tetrapolar rheography is used as a basic medical technique in the "Reodin - 500" complex. The main advantages of the method are high information content, complete safety for the patient, the possibility of continuous long-term monitoring, etc. The unit for computer analysis of RPKA 2 - 01 TU 9442-002-00271802-95 is designed to work as part of hardware-software complexes for medical purposes.

\section{Results of research and Their Analysis}

Heart rate (HR) in athletes with disabilities with amputations of the lower extremities alone was $84.5 \pm 1.8$ beats $/ \mathrm{min}$. Upon completion of the muscular load in the form of acceleration along the perimeter of the basketball court for 3 minutes, 
the heart rate indices were $155.4 \pm 2.1$ beats $/ \mathrm{min}$. This value by 70.9 beats/min was higher compared with the HR parameters recorded before the muscular load was fulfilled $(\mathrm{P}<0.05)$. In the subsequent minutes of rest, the heart rate of this group of athletes gradually decreased. In the second minute after the completion of the muscular load, the heart rate of these athletes decreased compared to the previous period by 17.9 beats $/ \mathrm{min}$ and amounted to $137.5 \pm 1.8$ beats/min $(P<0.05)$. In the third minute of the recovery process, the heart rate was $117.4 \pm 1.7$ beats/min. This value by 20.1 beats/min was lower compared to the HR indicators recorded in the second minute of the recovery process $(\mathrm{P}<0.05)$. In the fourth minute of the recovery process, the heart rate indicators for these athletes increased slightly compared with the previous period and amounted to $121.9 \pm 1.8$ beats/min, which was 4.5 beats/min higher than the heart rate recorded in the third minute of rest $(\mathrm{P}<0.05)$. By the fifth minute of the recovery process, heart rate indicators in athletes with lower limb amputations had decreased by 14.4 beats/min compared with the previous period and were 107.5 \pm 1.9 beats $/ \min (\mathrm{P}<0.05)$. In the sixth minute of the recovery process, the HR values for these athletes dropped to $97.8 \pm 1.7$ beats $/ \mathrm{min}$, which was 9.7 beats/min less than previous values $(P<0.05)$. In the seventh minute of the rest of the basketball players with amputations of the lower limbs, the HR decreased to approximately the level of the initial values and amounted to $89.5 \pm 2.1$ beats/min. Thus, in the seventh minute of the recovery process, heart rate indicators for basketball players in wheelchairs with lower limb amputations were established at about the initial values, i.e. HR recovery has occurred.

Summarizing the above, it can be noted that in basketball players who are wheelchairs with amputated lower limbs, when performing a muscular load, heart rate indices increase in comparison with the initial data approximately twice. Subsequently, the heart rate values are significantly reduced. However, the rate of recovery of the heart rate within seven minutes of rest is not the same. Thus, the most significant decrease in heart rate is observed in the second and third minutes of rest, where the heart rate decreased, respectively, by 17.9 and 20.1 beats $/$ min $(P<0.05)$. In the subsequent minutes of rest, the recovery rates of the heart rate were significantly lower. The decrease in heart rate to about the level of baseline values occurred in the seventh minute of rest. Thus, within seven minutes of rest after completion of the 3-minute muscular load, the heart rate indicators of basketball players with amputated lower limbs heart rate will recover to their original values.

Heart rate in athletes with disabilities with atrophy of the lower limbs, the heart rate at rest was $75.7 \pm 2.1$ beats $/ \mathrm{min}$. Upon completion of the muscular load in the form of acceleration along the perimeter of the basketball court within 3 minutes, the heart rate indicators were $171.5 \pm 2.0$ beats/min. This value was 95.8 beats/min higher than the registered heart rate recorded before the muscular load was fulfilled $(\mathrm{P}<0.05)$. In the subsequent minutes of the recovery process, the heart rate gradually decreased. In the second minute of rest, the HR decreased by 23.6 beats $/ \mathrm{min}$ and amounted to $147.9 \pm 1.8$ beats $/ \mathrm{min}$ $(\mathrm{P}<0.05)$. In the third minute of the recovery process, the heart rate was $131.7 \pm 1.9$ beats $/ \mathrm{min}$. This value by 16.2 beats/min was lower compared with the heart rate recorded in the second minute of the recovery process $(\mathrm{P}<0.05)$. In the fourth minute of the recovery process, heart rate indices decreased to $116.5 \pm 1.7$ beats $/ \mathrm{min}$. On the next three minutes of rest, i.e., on the fifth, sixth and seventh minutes of the recovery process, the heart rate of these athletes decreased by about $10-12$ beats/min $(\mathrm{P}<0.05)$. Recovery of heart rate values to approximately the initial level, we observed at 8 minutes of rest.

Consequently, in basketball players with atrophy of the lower extremities, only by the eighth minute of rest, heart rate indicators recovered to the level of baseline values and amounted to $84.9 \pm 1.7$ beats/min.

Summarizing the above, it can be noted that in basketball with amputated lower limbs, heart rate indicators at rest, according to our data, are significantly higher than in basketball with atrophy of the lower limbs. Further, it should be emphasized that athletes with amputated lower limbs, when performing muscular load in the form of shuttle acceleration around the perimeter of the site, responded by increasing the heart rate to 155.4 beats/min, then athletes with lower limb atrophy responded to the same load by increasing the heart rate to 171.5 beats/min The difference was 16.1 beats/min $(\mathrm{P}<0.05)$. More than, for basketball players with amputated lower limbs, recovery of heart rate to approximately the level of baseline values occurred on the seventh minute of rest, then in athletes with lower limb atrophy, this was observed only on the 8 th minute of the recovery process.

Therefore, it can be argued that among basketball players in wheelchairs the response of the heart rate and the recovery time after the completion of the muscular load depends on the nature of the injuries of the athletes.

Table 1. Changes in heart rate in wheelchair basketball players after doing a muscular load 


\begin{tabular}{|c|c|c|c|c|c|c|c|c|c|}
\hline \multirow{2}{*}{$\begin{array}{l}\text { Group of studied } \\
\text { athletes }\end{array}$} & \multirow{2}{*}{$\begin{array}{l}\text { Original } \\
\text { Heart } \\
\text { rate }\end{array}$} & \multicolumn{8}{|c|}{ Recovery time after the load } \\
\hline & & $1 \mathrm{~min}$ & $2 \min$ & $3 \mathrm{~min}$ & $4 \mathrm{~min}$ & $5 \mathrm{~min}$ & $6 \mathrm{~min}$ & $7 \mathrm{~min}$ & $8 \mathrm{~min}$ \\
\hline $\begin{array}{l}\text { Athletes with } \\
\text { amputation of the } \\
\text { lower extremities }\end{array}$ & $\begin{array}{l}84,5 \\
\pm 1,8\end{array}$ & $\begin{array}{l}155,4 \\
\pm 2,1 \\
*\end{array}$ & $\begin{array}{l}137,5 \\
\pm 1,8 \\
*\end{array}$ & $\begin{array}{l}117,4 \\
\pm 1,7 \\
*\end{array}$ & $\begin{array}{l}121,9 \\
\pm 1,8\end{array}$ & $\begin{array}{l}107,5 \\
\pm 1,9 \\
*\end{array}$ & $\begin{array}{l}97,8 \\
\pm 1,7 \\
*\end{array}$ & $\begin{array}{l}89,5 \\
\pm 2,1\end{array}$ & $\begin{array}{l}85,1 \\
\pm 1,7\end{array}$ \\
\hline $\begin{array}{l}\text { Athletes with } \\
\text { atrophy of the } \\
\text { lower extremities }\end{array}$ & $\begin{array}{l}75,7 \\
\pm 2,1\end{array}$ & $\begin{array}{l}171,5 \\
\pm 2,0 \\
*\end{array}$ & $\begin{array}{l}147,9 \\
\pm 1,8 \\
*\end{array}$ & $\begin{array}{l}131,7 \\
\pm 1,9 \\
*\end{array}$ & $\begin{array}{l}116,5 \\
\pm 1,7 \\
*\end{array}$ & $\begin{array}{l}128,9 \\
\pm 1,8\end{array}$ & $\begin{array}{l}111,5 \\
\pm 2,0 \\
*\end{array}$ & $\begin{array}{l}91,7 \\
\pm 1,6 \\
*\end{array}$ & $\begin{array}{l}84,9 \\
\pm 1,7\end{array}$ \\
\hline
\end{tabular}

*- the difference is significant compared with the previous value $(\mathrm{P}<0.05)$.

The stroke volume of disabled athletes with amputation of the lower limbs alone was $45.7 \pm$ $1.9 \mathrm{ml}$. Upon completion of the muscular load in the form of acceleration around the perimeter of the basketball court for 3 minutes, the values of the CRM were $85.4 \pm 1.7$ beats $/ \mathrm{min}$. This value by $39.7 \mathrm{ml}$ was higher compared to the values of CRI registered before performing the muscular load $(\mathrm{P}$ $<0.05$ ). In the subsequent minutes of rest, the systolic value of this group of athletes gradually decreased. In the second minute after the completion of the musculoskeletal system muscle mass, these athletes decreased compared to the previous period by $7.9 \mathrm{ml}$ and amounted to $77.5 \pm$ $1.5 \mathrm{ml}$. Although this value does not reach reliable values, however, there is a steady downward trend in stroke volume. In the third minute of the recovery process, the CRM was $64.9 \pm 1.7 \mathrm{ml}$. This value of $12.6 \mathrm{ml}$ was less compared with the values of the ACE registered in the second minute of the recovery process $(P<0.05)$. In the fourth minute of the recovery process, the trend towards a decrease in the CRI continued and in these athletes, the systolic blood volume decreased to $57.4 \mathrm{ml}$. In the fifth minute of the recovery process in basketball players with amputations of the lower extremities, there was a decrease in the CRI to approximately the level of the initial values, and amounted to $47,5 \pm 2.1 \mathrm{ml}$. Thus, in the fifth minute of the recovery process, the CRI indicators for wheelchair players with amputations of the lower limbs were established at about the level of the initial values, i.e. recovery of stroke volume has occurred. In the subsequent minutes of the recovery process, i.e. at the sixth, seventh, and eighth minutes of rest, the values of the AEC in these athletes did not undergo significant changes, remaining at about 45-46 $\mathrm{ml}$.

The stroke volume of athletes with disabilities with atrophy of the lower extremities alone was $57.5 \pm 2.1 \mathrm{ml}$. Upon completion of the muscular load in the form of acceleration along the perimeter of the basketball court for 3 minutes, the CRI figures were $78.4 \pm 1.6 \mathrm{ml}$. This value by $20.9 \mathrm{ml}$ was higher compared with the values of
CRI registered before performing the muscular load $(\mathrm{P}<0.05)$. In the subsequent minutes of the recovery process, the stroke volume of these athletes gradually decreased. In the second minute of rest, the ASC was $81.4 \pm 1.7 \mathrm{ml}$ In the third minute of the recovery process, the CRM was $74.5 \pm 1.9 \mathrm{ml}$. On the fourth, fifth, sixth and seventh minutes of rest, the stroke volume of these blood athletes had a steady downward trend, gradually decreasing by an average of 7-9 $\mathrm{ml}$ per minute. Recovery of the values of the CRM to approximately the initial level, we observed at 8 minutes of rest. Consequently, in basketball players with atrophy of the lower extremities, only by the eighth minute of rest did the heart rate return to the level of baseline values and amounted to $58.5 \pm 2.0 \mathrm{ml}$.

Summarizing the above, it can be noted that, in basketball players with amputated lower limbs, the WAA indicators at rest, according to our data, are significantly lower than those of basketball players with atrophy of the lower limbs. Further, it should be emphasized that athletes with amputated lower limbs, when performing a muscular load in the form of shuttle acceleration around the perimeter of the site, responded by increasing the AEC to $85.4 \pm 2.0 \mathrm{ml}$, whereas athletes with atrophy of the lower limbs responded to the same load by increasing the AUR 78.4 \pm $1.6 \mathrm{ml}$. The difference was $7.0 \mathrm{ml}(\mathrm{P}<0.05)$. Moreover, while in basketball players with amputated lower limbs, recovery of the CRM approximately to the level of the initial values occurred in the fifth minute of rest, in athletes with lower limb atrophy this was observed only in the eighth minute of the recovery process.

Therefore, it can be argued that in basketball players with wheelchairs, the response of the AOC and the recovery time after the completion of the muscular load depends on the nature of the injuries of the athletes. According to our data, athletes with amputation of the lower extremities had the best results, compared with athletes with atrophy of the lower extremities.

Table 2. UAC changes in wheelchair basketball players after doing a muscular load 
*- the difference is significant compared with the previous value $(\mathrm{P}<0.05)$.

\section{Conclusion}

Systematic muscle training makes significant demands on the body of athletes with disabilities $[2,3,4]$. Moreover, the number of works devoted to the study of the functional capabilities of the body of persons with disabilities is few. of the heart rate and CRM and the recovery time after the completion of the muscular load depends on the nature of the injuries of the athletes. Athletes with amputated lower limbs are characterized by the greatest response of the CRM to muscle load and the most rapid recovery of stroke volume. Athletes with atrophy of the lower extremities, these results were slightly lower. Consequently, when planning and conducting the training sessions themselves, coaches need to take

\begin{tabular}{|l|l|l|l|l|l|l|l|l|l|}
\hline Group of studied & \multirow{2}{*}{$\begin{array}{l}\text { Original } \\
\text { athletes }\end{array}$} & \multicolumn{2}{|l|}{ Recovery time after the load } \\
\cline { 3 - 11 } & $1 \mathrm{~min}$ & $2 \mathrm{~min}$ & $3 \mathrm{~min}$ & $4 \mathrm{~min}$ & $5 \mathrm{~min}$ & $6 \mathrm{~min}$ & $7 \mathrm{~min}$ & $8 \mathrm{~min}$ \\
\hline $\begin{array}{l}\text { Athletes with } \\
\text { amputation of the } \\
\text { lower extremities }\end{array}$ & $\begin{array}{l}45,7 \\
\pm 1,9\end{array}$ & $\begin{array}{l}85,4 \\
\pm 1,7\end{array}$ & $\begin{array}{l}77,5 \\
\pm 1,5\end{array}$ & $\begin{array}{l}64,9 \\
\pm 1,7\end{array}$ & $\begin{array}{l}57,4 \\
\pm 1,4\end{array}$ & $\begin{array}{l}47,5 \\
\pm 2,1\end{array}$ & $\begin{array}{l}45,9 \\
\pm 1,9\end{array}$ & $\begin{array}{l}47,5 \\
\pm 1,5\end{array}$ & $\begin{array}{l}46,5 \\
\pm 1,8\end{array}$ \\
\hline $\begin{array}{l}\text { Athletes with } \\
\text { atrophy of the } \\
\text { lower extremities }\end{array}$ & $\begin{array}{l}57,5 \\
\pm 2,1\end{array}$ & $\begin{array}{l}78,4 \\
\pm 1,6\end{array}$ & $\begin{array}{l}81,4 \\
\pm 1,7\end{array}$ & $\begin{array}{l}74,5 \\
\pm 1,9\end{array}$ & $\begin{array}{l}69,5 \\
\pm 1,5\end{array}$ & $\begin{array}{l}70,4 \\
\pm 1,9\end{array}$ & $\begin{array}{l}67,5 \\
\pm 2,0\end{array}$ & $\begin{array}{l}63,7 \\
\pm 1,7\end{array}$ & $\begin{array}{l}58,5 \\
\pm 2,0\end{array}$ \\
\hline
\end{tabular}

Moreover, in the available literature, it is extremely rare to find works devoted to the study of the pumping function of the heart of people with disabilities who are systematically engaged in muscle training. For a more complete picture of the functional capabilities of the heart, it is advisable to carry out studies of the activity of the heart directly during the execution of muscle loads $[2,6,13,14,15]$. Moreover, changes in heart rate indicators in the recovery process, especially immediately after the cessation of muscle activity, indicate the most important regulatory changes in the body. In this regard, we investigated the response of the pumping function of the heart of disabled athletes to the performance of muscular load in the form of shuttle acceleration for three minutes around the perimeter of the basketball court.

As our studies have shown, in wheelchair players with various injuries during the performance of the muscular load and in the recovery process, we identified the following features:

- among basketball players with amputated lower limbs, the WAF alone was significantly lower, and the heart rate was higher than that of basketball players with atrophy of the lower limbs;

- basketball players with amputated lower limbs react to a muscular load with a greater response from the ASC than athletes with atrophied lower limbs.

- in basketball with amputated lower limbs, the recovery of heart rate and CRM approximately to the level of the initial values after the completion of the muscular load occurred much earlier than in basketball players with atrophy of the lower limbs.

Thus, summing up the above, it can be noted that in basketball players - wheelchairs, the response these physiological features into account and make certain adjustments to the process of sports training of wheelchair basketball players.

In our opinion, athletes with amputation of the lower extremities undergo a significant restructuring of central hemodynamics. First of all, it concerns the volume values of the systemic blood flow. The degree of decrease in shock blood volume, according to scientists, is directly dependent on the level of amputation. The decrease in circulating blood volume ranges from $7.0 \%$ in persons with disabilities after amputation at the level of the tibia to $19.3 \%$ in persons with disabilities who undergo amputation of both lower limbs at the level of the thighs or thighs and shin. Probably, a regular decrease in volumetric values occurs, myocardial contractility decreases, and blood circulation stabilizes at a new physiological level, adequate to the body's energy needs, which is confirmed by normal values of relative indicators and the absence of any signs of circulatory failure.

\section{Findings}

1. In basketball players with amputated lower limbs, the WAF alone is significantly lower, and the heart rate is higher than that of basketball players with atrophy of the lower limbs.

2. Basketball players with amputated lower limbs respond to a muscular load with a greater response from the ASC than athletes with atrophied lower limbs.

3. In basketball with amputated lower limbs, recovery of heart rate and CRM approximately to the level of baseline values after the completion of the muscular load occurs much earlier than in basketball players with atrophy of the lower limbs. 


\section{Acknowledgments}

The work is performed according to the Russian Government Program of Competitive Growth of Kazan Federal University.

\section{References}

1. Bryukhovetsky A.S. Spinal cord injury: cellular technologies in treatment and rehabilitation / Bryukhovetsky A.S. Moscow: Practical medicine, 2010. - 341 p.

2. Vakhitov I.Kh. Changes in stroke volume of young athletes in the recovery period after performing the Harvard step test // Theor. and practical FK.- 1999.- № 8.- p. 30-32.

3. G. Verich. Features of hemodynamics in disabled persons - athletes with a lesion of the musculoskeletal system / G. Verich, O. Lukovskaya,

Y. Vdovichenko, O. Kovalenko // Science in Olympic sport. - 2002. -№ 2. - P.53-56.

4. Kobzev Yu.A. Some features of the reaction of the cardiovascular system to physical stress in amputee persons involved in sports / Kobzev Yu.A., Khramov VV // Theory and practice of physical culture. 2002. - № 7. - p. 13-16

5. Sakharova O.V. Comprehensive treatment with the use of adaptive sports in the rehabilitation of patients with spinal injuries: author. dis $\ldots$ Cand. honey. Sciences ; Sakharova OV - Perm, 2005. -23 p.

6. Features of the cardiorespiratory system and the autonomous regulation of parasols with spinal injury / Ternova K.S. [et al.] // Human Physiology. - 2012. - V. 38, № 4. P. 83-88.

7. Bombardier C.H. Implications for screening / Bombardier C.H. [et al.] // Archives of Physical Medicine and Rehabilitation. - 2004. - No 85. - p. 17491756.

8. The relationship between post-traumatic stress disorder following M.C. [et al.] // J Affective Dis. - 2006. - No 93. - p. 229-232.

9. The psychological impact of patients / Gioia M. [et al.] // Scand J Med Sci Sports. 2006. - No 16 (6). - P. 412-

10. Malec J. Psychologic prediction of duration of spinal cord injury / Malec J., Neimeyer R. // Arch Phys Med Rehabil. 1983. - No 64 (8). - p. 359-363.

11. Kalpakjian C.Z. Measuring depression in persons with spinal cord injury: a systematic review / Kalpakjian C.Z. [et ai.] // J Spinal Cord Med. - 2009. - No 32 (1). - P. 6-24.

12. Kubicek WG, Kamegis JW, Patterson RP, Witsoe DA, Mattson RH. Development and evaluation of an impedance cardiac output system. Aerospace Med 1967.37: 1208-12

13. Vakhitov I.H. Catecholamine Excretion in Individuals Engaged in Extreme Sports / A.V. Izosimova, I.H. Vakhitov, T.L. Zefirov
Pharmaceutical Sciences. - 2017. - 4 (9). - P. 3040-3043.

14. Vakhitov I. Kh. Changes in blood volume shock / B.I. Vakhitov, T.L. Zefirov, I. Kh. Vakhitov // Drug Invention Today Vol 10 - Special Issue 3 - 2018. - p. 31973199 .

15. Vakhitov I.Kh. Stroke of the bloodstream after muscular load / B.I. Vakhitov*, I. Kh. Vakhitov, A. H. Volkov, S. S. Chinkin // Journal of Pharmacy Research. -2017, -Vol. 11, -P. 1198 - 1200.

16. Eisvandi, M., Gorji, Y., \& Niknejadi, F. (2015). Effectiveness of Emotional Intelligence on Increasing the Psychological Dimension of Quality of Life of Mothers of Educable Mentally Retarded Children in Esfahan in. UCT Journal of Social Sciences and Humanities Research, 3(1), 29-31.

17. Tagay, A., \& Ballesteros, L. (2016) ILOCANO FAMILISM IN THE CHICHACORN INDUSTRY IN PAOAY,
ILOCOS

PHILIPPINES. Humanities \& Social Sciences Reviews, 4(1), 27-40. https://doi.org/10.18510/hssr.2016.414 